\title{
Konsep Pendidikan Islam dan Perkembangannya dalam Menghadapi Problem Pendidikan
}

\author{
Oleh: \\ SITI MAKHMUDAH \\ STAIM Nglawak Kertososno \\ Email: makhmudahsiti87@gmail.com
}

\begin{abstract}
Islamic education is education that is conscious and purposeful, God has established a clear educational foundation for all humans through Islamic law. The concept of education in Islam is, First, Education is an activity that must have clear goals, objectives and targets. Second,

The true and absolute educator is Allah SWT, He is the Creator of nature, the Giver of talent, the Maker of various sunnah developments, enhancements, and interactions of nature as He also prescribes the rules in order to realize the perfection, benefit and happiness of the nature. Third, education demands the realization of a tiered program through increased education and teaching activities in line with children's development. Fourth, the role of an educator must be in accordance with the purpose of AllahSWT creating it.
\end{abstract}

Keywords: The concept of Islamic education, The problem of education

\section{PENDAHULUAN}

Islam sebagai agama universal memiliki sistem pendidikan yang sempurna untuk seluruh umat manusia di muka bumi. Pada makalah ini akan dipaparkan mengenai sumber, landasan, metode, sarana, sejarah hingga berbagai persoalan yang kerap melanda dunia pendidikan kita. Selain itu akan dibahas mengenai beberapa pemahaman pendidikan yang digunakan dalam konsep islam yang bersandar pada al-Qur`an (asal kata tarbiyyah), yaitu sebagai berikut :

1. Menyampaikan sesuatu hingga mencapai kesempurnaan (Imam al-Baidhawi dalam buku Anwarat-Tanzilwa`Asrarat-Ta`wil)

2. Menumbuhkan perilaku demi perilaku secara bertahap hingga mencapai batasan kesempurnaan (Ar-Raghib al-Ashfahani dalam buku Mufradat)

3. Dalam Pendidikan tercakup 3 unsur yaitu: a. menjaga dan memelihara anak, b. mengembangkan bakat dan potensi anak sesuai kekhasan masing-masing, 
c. mengarahkan bakat dan potensi untuk mencapai kebaikan dan kesempurnaan (Abdurrahman al-Bani).

Dari pengertian-pengertian di atas, dapat disimpulkan bahwa, pertama, pendidikan merupakan kegiatan yang harus memiliki tujuan, sasaran dan target yang jelas. Kedua, Pendidik yang sejati dan mutlak adalah Allah SWt, Dialah Pencipta fitrah, Pemberi bakat, Pembuat berbagai sunnah perkembangan, peningkatan, dan interaksi fitrah sebagaimana Dia pun mensyariatkan aturan guna mewujudkan kesempurnaan, kemaslahatan dan kebahagiaan fitrah tersebut. Ketiga, pendidikan menuntut terwujudnya program berjenjang melalui peningkatan kegiatan pendidikan dan pengajaran selaras dengan perkembangan anak. Keempat, peran seorang pendidik harus sesuai dengan tujuan Allah SWT menciptakannya.

Kajian pada konsep pendidikan Islam membawa kita pada konsep syariat dan agama karena bagaimanapun agamalah yang harus menjadi akar pendidikan kita. Islam merupakan syari at Allah bagi manusia yang dengan bekal syariat itu manusia beribadah. Agar manusia mampu memikul dan merealisasikan amanat berat tersebut, syariat itu membutuhkan pengamalan, pengembangan dan pembinaan. Pengembangan dan pembinaan itulah yang dimaksud dengan pendidikan Islam.

Pendidikan Islam mengantarkan manusia pada perilaku dan perbuatan manusia yang berpedoman pada syariat Allah. Tiga bentuk pendidikan yang dapat membawa pada tujuan tersebut adalah,

1) pendidikan individu yang membawa manusia pada keimanan dan ketundukan kepada syariat Allah SWT

2) Pendidikan diri yang membawa manusia pada amal shaleh dalam menjalani hidupnya sehari-hari dan

3) pendidikan masyarakat yang membawa manusia pada sikap saling mengingatkan dalam kebenaran (berdasarkanQ.S.Al-Ashr;1-3) 


\section{Pembahasan}

\section{Konsep Pendidikan Islam}

\section{a. Arti Pendidikan Islam}

Istilah umum yang digunakan dalam pendidikan Islam, yaitu Tarbiyah (pengetahuan tentang ar-rabb), Ta'lim (ilmu teoritik, kreativitas, komitmen tinggi dalam mengembangkan ilmu, serta sikap hidup yang menjunjung tinggi nilai-nilai ilmiah), Ta' dib (integrasi ilmu dan amal) ${ }^{1}$.

1. Istilah Tarbiyah

Kata Tarbiyah berasal dari kata dasar "Rabba" ( ), yurabbi (يُرَبِّى) menjadi "tarbiyah" yang berarti memelihara, membesarkan dan mendidik. Dalam statusnya sebagai khalifah berarti manusia hidup di alam mendapat kuasa dari Allah untuk mewakili sekaligus sebagai pelaksana dari peran dan fungsi Allah di alam. Dengan demikian manusia sebagai bagian dari alam memiliki potensi untuk tumbuh dan berkembang bersama alam lingkungannya. Tetapi sebagai khalifah Allah maka manusia memiliki tugas untuk memadukan pertumbuhan dan perkembangannya bersama dengan alam ${ }^{2}$.

2. Istilah Ta'lim

Secara etimologi, ta'lim berkonotasi pembelajaran, yaitu proses memindahkan ilmu pengetahuan. Hakekat ilmu pengetahuan bersumber dari Allah SWT. Adapun proses pembelajaran (ta'lim) secara simbolis dinyatakan dalam informasi al-Qur'an ketika penciptaan Adam as oleh Allah SWT, ia menerima pemahaman tentang konsep ilmu pengetahuan langsung dari penciptanya. Proses pembelajaran ini disajikan dengan menggunakan konsep ta'lim yang sekaligus menjelaskan hubungan antara pengetahuan Adam as dengan Tuhannya ${ }^{3}$.

3. Istilah Ta'dib

Menurut al-Attas, istilah yang paling tepat untuk menunjukkan pendidikan Islam adalah Ta'dib, konsep ini didasarkan pada hadits Nabi:

\footnotetext{
${ }^{1}$ Endang Saefuddin Anshari, Pokok-Pokok Pikiran tentang Islam, Usaha Enterprise, Jakarta: Media Citra, 1976

2 Azyumardi Azra, Pendidikan Islam, Tradisi dan Modernisasi Menuju Milenium Baru, Jakarta: Logos, Wacana Ilmu. 1997

${ }^{3}$ MuzayyinArifin, Filsafat Pendidikan Islam, Jakarta: Bumi Aksara, 2003
} 


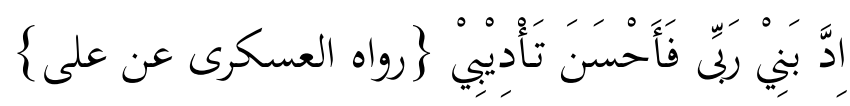

Artinya : "Tuhan telah mendidikku, maka ia sempurnakan pendidikanku" (HR. al-Askary dari Ali r.a).

Ta'dib berarti pengenalan dan pengetahuan secara berangsur-angsur yang ditanamkan ke dalamdiri manusia (peserta didik) tentang tempat-tempat yang tepat dari segala sesuatu di dalam tatanan penciptaan. Dengan pendekatan ini pendidikan akan berfungsi sebagai pembimbing ke arah pengenalan dan pengakuan tempat Tuhan yang tepat dalam tatanan wujud dan kepribadiannya.

Dari bahasan di atas dapat disimpulkan bahwa pendidikan Islam adalah suatu sistem yang memungkinkan seseorang (peserta didik) dapat mengarahkan kehidupannya sesuai dengan ideologi Islam ${ }^{4}$.

Penyelenggaraan pendidikan dalam lintasan sejarah Islam telah dimulai oleh Rasulullah saw dan para Khulafa ar-Rasyidin. Rasulullah saw telah menjadikan mengajar baca-tulis bagi 10 orang penduduk Madinah sebagai syarat pembebasan bagi setiap tawanan perang Badar. Pada masa itu nabi Muhammad senantiasa menanamkan kesadaran pada sahabat dan pengikutnya akan urgensi ilmu dan selalu mendorong umat untuk senantiasa mencari ilmu. Hal ini dapat kita buktikan dengan adanya banyak hadis yang menjelaskan tentang urgensi dan keutamaan (hikmah) ilmu dan orang yang memiliki pengetahuan. Khalifah Umar bin Khattab, secara khusus, mengirimkan 'petugas khusus' ke berbagai wilayah baru Islam untuk menjadi guru pengajar bagi masyarakat Islam di wilayahwilayah tersebut.

Institusi pendidikan Islam yang mulai menggunakan sistem pendidikan 'modern' baru muncul dengan berdirinya Perguruan al-Azhar oleh Daulat Bani Fatimiyyah di Kairo pada tahun 972 M. Pada al-Azhar, selain dilengkapi dengan perpustakaan dan laboratorium, mulai diberlakukan sebuah kurikulum pengajaran. Pada kurikulum al-Azhar diajarkan disiplin-disiplin ilmu agama dan juga disiplin-

\footnotetext{
${ }^{4}$ HornbyCowie, Oxford Advanced Learners Dictionary of Current English, London:Oxford University Press, 1974
} 
disiplin ilmu 'umum' (aqliyyah). Ilmu agama yang ada dalam kurikulum al-Azhar antara lain tafsir, hadits, fiqh, qira'ah, teologi (kalam), sedang ilmu akal yang ada dalam kurikulum al-Azhar antara lain filsafat, logika, kedokteran, matematika, sejarah dan geografi.

\section{b. Konsep Pendidikan Menurut Islam}

Merujuk kepada informasi al-Qur'an pendidikan mencakup segala aspek jagat raya ini, bukan hanya terbatas pada manusia semata, yakni dengan menempatkan Allah sebagai Pendidik Yang Maha Agung. Secara garis besar, konsepsi pendidikan dalam Islam adalah mempertemukan pengaruh dasar dengan pengaruh ajar. Pengaruh pembawaan dan pengaruh pendidikan diharapkan akan menjadi satu kekuatan yang terpadu yang berproses ke arah pembentukan kepribadian yang sempurna. Oleh karena itu, pendidikan dalam Islam tidak hanya menekankan kepada pengajaran yang berorientasi kepada intelektualitas penalaran, melainkan lebih menekankan kepada pendidikan yang mengarah kepada pembentukan keribadian yang utuh dan bulat.

Konsep pendidikan islam yang mengacu kepada ajaran Al-Qur'an, sangat jelas terurai dalam kisah Luqman. Dr. M. Sayyid Ahmad Al-Musayyar menukil beberapa ayat Al-Qur'an dalam Surat Luqman. Beliau mengatakan, ada tiga kaedah asasi pendidikan dalam Islam menurut Al-Qur'an yang dijalankan oleh Luqman kepada anaknya. Seperti diketahui, Luqman diberikan keutamaan Allah berupa Hikmah, yaitu ketepatan bicara, ketajaman nalar dan kemurnian fitrah. Dengan keistimewaannya tersebut, Luqman ingin mengajari anaknya hikmah dan membesarkannya dengan metode hikmah itu pula.

Kaidah pendidikan yang pertama adalah peletakan pondasi dasar, yaitu penanaman keesaan Allah, kelurusan aqidah, beserta keagungan dan kesempurnaan-Nya. Kalimat tauhid adalah focus utama pendidikannya. Tidak ada pendidikan tanpa iman. Tak ada pula akhlak, interaksi social, dan etika tanpa iman. Apabila iman lurus, maka lurus pulalah aspek kehidupannya. Mengapa? Sebab iman selalu diikuti oleh perasaan introspeksi diri dan takut terhadap Allah. Dari sinilah Luqman menegaskan hal itu kepada puteranya dengan berkata, “"'Hai 
180 - 199 | Tafhim Al-`Ilmi, Februari 2020

anakku, sesungguhnya jika ada (sesuatu perbuatan) seberat biji sawi, dan berada dalam batu atau di langit atau di dalam bumi, niscaya Allah akan mendatangkannya (membalasinya). Sesungguhnya Allah Maha Halus lagi Maha Mengetahui.” (QS. 31:16). Seorang mukmin mesti berkeyakinan bahwa tak ada satu pun yang bias disembunyikan dari Allah. Allah Maha Mengetahui apa yang ada dalam lipatan hati manusia. Dari sinilah ia akan melakukan seluruh amal dan aktivitasnya semata untuk mencari ridha Allah tanpa sikap riya atau munafik, dan tanpa menyebut-nyebutnya ataupun menyakiti orang lain.

Kaidah kedua dalam pendidikan menurut Luqman adalah pilar-pilar pendidikan. Ia memerintahkan anaknya untuk shalat, memikul tanggung jawab amar ma'ruf nahi munkar, serta menanamkan sifat sabar. Shalat adalah cahaya yang menerangi kehidupan seorang muslim. Ini adalah kewajiban harian seorang muslim yang tidak boleh ditinggalkan selama masih berakal baik.

Amar ma'ruf nahi munkar merupakan istilah untuk kritik konstruktif, rasa cinta dan perasaan bersaudara yang besar kepada sesame, bukan ditujukan untuk mencari-cari kesalahan dan ghibah. Ummat islam telah diistimewakan dengan tugas amar ma'ruf nahi munkar ini melalui firman-Nya, "Kamu adalah umat yang terbaik yang dilahirkan untuk manusia, menyuruh kepada yang ma'ruf, dan mencegah dari yang munkar, dan beriman kepada Allah. Sekiranya Ahli Kitab beriman, tentulah itu lebih baik bagi mereka, di antara mereka ada yang beriman, dan kebanyakan mereka adalah orang-orang yang fasik. " (QS: 3.110) .

Sabar itu bermacam-macam. Ada sabar atas ketaatan hingga ketaatan itu ditunaikan, ada sabar atas kemaksiatan hingga kemaksiatan itu dihindari, dan ada pula sabar atas kesulitan hidup hingga diterima dengan perasaan ridha dan tenang. Seorang beriman berada di posisi antara syukur dan sabar. Dalam kemuddahan yang diterimanya, ia pandai bersyukur. Sedang dalam setiap kesulitan yag dihadapinya, ia mesti bersabar dan introspeksi diri.

\footnotetext{
${ }^{5}$ Shihab, Umar, Kontekstualitas Al-Qur'an; Kajian Tematik Atas Ayat-Ayat Hukum Dalam Al-Qur'an, Jakarta: Penamadani, 2005
} 
Kaidah ketiga adalah etika social. Metode pendidikan Luqman menumbuhkan buah adab yang luhur serta keutamaan-keutamaan adiluhung. Luqman menggambarkan hal itu untuk putranya dengan larangan melakukan kemungkaran dan tak tahu terima kasih, serta perintah untuk tidak terlalu cepat dan tidak pula terlalu lambat dalam berjalan, dan merendahkan suara. Seorang muslim perlu diingatkan untuk tidak boleh menghina dan angkuh. Sebab, semua manusia berasal dari nutfah yang hina dan akan berakhir menjadi bangkai busuk. Dan ketika hidup pun, ia kesakitan jika tertusuk duri dan berkeringat jika kepanasan.

Sebenarnya, pendidikan dapat diartikan secara sederhana sebagai upaya menjaga anak keturunan agar memiliki kualitas iman prima, amal sempurna dan akhlak paripurna. Karena itu, tanpa banyak diketahui, di dalam islam, langkah awal pendidikan untuk mendapatkan kualitas keturunan yang demikian sudah ditanamkan sejak anak bahkan belum terlahir. Apa buktinya? Manhaj islam menggariskan bahwa sebaik-baik kriteria dalam memilih pasangan hidup adalah factor agama, bukan karena paras muka dan kekayaannya. Sebab, diyakini, calon orang tua yang memiliki keyakinan beragama yang baik tentu akan melahirkan anak-anak yang juga baik.

Di dalam ajaran islam, orang tua bertanggung jawab terhadap pendidikan anak-anaknya. Keduanya berkewajiban mendidik anak-anaknya untuk mempertemukan potensi dasar dengan pendidikan, sebagaimana sabda

Nabi Muhammad saw yang menyatakan bahwa : "Setiap anak dilahirkan di atas fitrahnya, maka kedua orangtuanya yang menjadikan dirinya beragama Yahudi, Nasrani, atau Majusi" (HR Bukhari). Kewajiban ini juga ditegaskan dalam firman-Nya: Dan perintahkanlah kepada keluargamu mendirikan shalat dan bersabarlah kamu dalam mengerjakannya. Kami tidak meminta rezki kepadamu, Kamilah yang memberi rezki kepadamu. Dan akibat (yang baik) itu adalah bagi orang yang bertakwa". Dalam ayal lain, "Hai orang-orang yang beriman, peliharalah dirimu dan keluargamu dari api neraka yang bahan bakarnya adalah manusia dan batu; penjaganya malaikat-malaikat yang kasar, keras, dan tidak 
182 - 199 | Tafhim Al-`Ilmi, Februari 2020

mendurhakai Allah terhadap apa yang diperintahkan-Nya kepada mereka dan selalu mengerjakan apa yang diperintahkan.

Dalam Islam, pentingnya pendidikan tidak semata-mata mementingkan individu, melainkan erat kaitannya dengan kehidupan sosial kemasyarakatan. Konsep belajar/pendidikan dalam Islam berkaitan erat dengan lingkungan dan kepentingan umat. Oleh karena itu, dalam proses pendidikan senantiasa dikorelasikan dengan kebutuhan lingkungan, dan lingkungan dijadikan sebagai sumber belajar. Seorang peserta didik yang diberi kesempatan untuk belajar yang berwawasan lingkungan akan menumbuhkembangkan potensi manusia sebagai pemimpin.

Firman Allah (QS Al Baqarah 30) menyatakan :"Sesungguhnya Aku jadikan manusia sebagai pemimpin (khalifah) di atas bumi”. Kaitan dengan pentingnya pendidikan bagi umat, Allah berfirman: "Hendaklah ada di antara kamu suatu ummat yang mengajak kepada kebajikan dan memerintahkan yang ma'ruf dan melarang yang mungkar. Mereka itulah orang-orang yang beruntung" (QS. 3:104) ${ }^{6}$.

Konsep pendidikan dalam Islam menawarkan suatu sistem pendidikan yang holistik dan memposisikan agama dan sains sebagai suatu hal yang seharusnya saling menguatkan satu sama lain, yang secara umum ditunjukkan dalam doa Rasulullah : "Ya Allah, ajarilah aku apa yang membawa manfaat bagiku, serta karuniakanlah padaku ilmu yang bermanfaat”. Dari doa tersebut terungkap bahwa kualitas ilmu yang didambakan dalam Islam adalah kemanfaatan dari ilmu itu. Hal ini terlihat dari hadits Rasulullah : "Iman itu bagaikan badan yang masih polos, pakaiannya adalah taqwa, hiasannya adalah rasa malu dan buahnya adalah ilmu."

Pemisahan dan pengotakan antara agama dan sains jelas akan menimbulkan kepincangan dalam proses pendidikan, agama jika tanpa dukungan sains akan menjadi tidak mengakar pada realitas dan penalaran, sedangkan sains yang tidak

\footnotetext{
${ }^{6}$ Shihab, Umar, Kontekstualitas Al-Qur'an; Kajian Tematik Atas Ayat-Ayat Hukum Dalam Al-Qur'an, Jakarta: Penamadani, 2005
} 
dilandasi oleh asas-asas agama dan akhlaq atau etika yang baik akan berkembang menjadi liar dan menimbulkan dampak yang merusak. Murtadha Mutahhari seorang ulama, filosof dan ilmuwan Islam menjelaskan bahwa iman dan sains merupakan karakteristik khas insani, di mana manusia mempunyai kecenderungan untuk menuju ke arah kebenaran dan wujud-wujud suci dan tidak dapat hidup tanpa menyucikan dan memuja sesuatu. Ini adalah kecenderungan iman yang merupakan fitrah manusia. Tetapi di lain pihak manusia pun memiliki kecenderungan untuk selalu ingin mengetahui dan memahami semesta alam, serta memiliki kemampuan untuk memandang masa lalu, sekarang dan masa mendatang (yang merupakan ciri khas sains).

Al-Qur'an berkali-kali meminta manusia membaca tanda-tanda alam, menantang akal manusia untuk melihat ke-MahaKuasa-an Allah pada makhluk lain, rahasia penciptaan tumbuhan, hewan, serangga, pertumbuhan manusia, kejadian alam dan penciptaan langit bumi. Banyak ayat-ayat Al-Qur'an yang berisikan tentang kejadian-kejadian di sekitar kita yang menuntut pemahaman dengan sains/akal manusia. Karena itu, seorang muslim juga diwajibkan untuk mempelajari sains, karena sains hanyalah salah satu pembuktian kekuasaan Allah, di samping ayat-ayat qauliyah. Karenanya, konsep pendidikan dalam islam menurut Al-Qur'an pun tidak hanya berisi materi-materi pendidikan keagamaan saja.

\section{c. Tujuan Pendidikan Islam}

Pendidikan Islam merupakan pendidikan yang berkesadaran dan bertujuan, Allah telah menyusun landasan pendidikan yang jelas bagi seluruh manusia melalui syariat Islam. Allah menciptakan alam semesta ini dengan tujuan yang jelas. Dia menciptakan manusia dengan tujuan untuk menjadi khalifah di muka bumi melalui ketaatan kepada-Nya. Untuk mewujudkan tujuan itu, Allah memberikan hidayah serta berbagai fasilitas alam semesta kepada manusia. Jika tugas manusia dalam kehidupan ini demikian penting, pendidikan harus memiliki tujuan yang sama dengan tujuan penciptaan manusia. Bagaimanapun pendidikan Islam sarat dengan pengembangan nalar dan penataan perilaku serta emosi 
184 - 199 | Tafhim Al-`Ilmi, Februari 2020

manusia dengan landasan agama. Dengan demikian tujuan pendidikan Islam adalah merealisasikan penghambaan kepada Allah dalam kehidupan manusia, baik secara individual maupun secara sosial.

Realisasi tujuan pendidikan melalui ibadah tidak diartikan sebagai upaya manusia yang hanya berfokus pada aspek ritual saja seperti shalat, membaca alQur`an dan lain-lain. Untuk menyempurnakannya ibadah dimaknai sebagai ketaatan yang mencakup seluruh aspek kehidupan. Namun demikian sistem pendidikan Islam saat ini banyak ditinggalkan oleh umat manusia, karena beranggapan pendidikan Islam tidak menyentuh seluruh aspek kehidupan, sehingga sistem yang digunakan lebih berorientasi pada sistem pendidikan yang berasal dari dunia barat, padahal itu adalah sebuah kekeliruan yang perlu diluruskan. Bahkan Sistem pendidikan Islam jika dibandingkan dengan sistem pendidikan lain memiliki keunggulan. Berikut ini adalah beberapa perbandingan konsep Islam dengan konsep yang dimunculkan pada konsep pendidikan barat.

a. Islam dan konsep aktualisasi diri

Konsep pendidikan Islam dalam memenuhi tujuan aktualisasi diri adalah, pertama, Allah memberikan kebebasan memilih kepada manusia serta menjelaskan konsekuensi pilihan yang dirasakan manusia di akhirat kelak. Kedua, Allah memberikan ajang kompetisi dalam kebaikan tetap terbuka bagi manusia. Prinsip yang Dia tekankan adalah penyesuaian balasan di akhirat kelak dengan perbuatan manusia di dunia. Ketiga, Allah menjadikan penghambaan dan ketaatan manusia pada-Nya sebagai tujuan tertinggi. Hanya itulah yang menjadikan tolok ukur aktualisasi diri dalam Islam. Keempat, Allah menciptakan manusia dan alam semesta ini dengan kemampuan yang membawa manusia pada perbedaan profesi sesuai keahliannya.

b. Islam dan Konsep perkembangan

Sebagian ahli dan filosof pendidikan menganggap bahwa tujuan inti pendidikan adalah perkembangan, baik perkembangan intelektual, fisik, batin, maupun sosial. Namun, konsepsi tersebut hanya terbatas pada perkembangan 
yang menyangkut perkembangan wujud, perubahan berat, penambahan pengetahuan, atau peningkatan kualitas pola kehidupan anak sejak lahir hingga dewasa yang menyangkut perilaku dan segala aktivitasnya. Sedangkan konsep pendidikan Islam memandang bahwa seluruh aspek perkembangan sebagai sarana mewujudkan aspek ideal, yaitu penghambaan dan ketaatan kepada Allah serta aplikasi keadilan dan syariat Allah dalam kehidupan sehari-hari. Dengan demikian pendidikan Islam mencakup pemeliharaan seluruh aspek perkembangan, baik itu aspek material, spiritual, intelektual, perilaku sosial, apresiasi atau pengalaman. Dan yang terpenting, Islam mengarahkan perkembangan tersebut ke arah perwujudan tujuan pendidikan yang tinggi.

\section{c. Pendidikan Islam dan Konsep Perkembangan Jasmani}

Dalam membina kekuatan fisik, Rasulullah SAW menganjurkan umat Islam untuk berolahraga, seperti berkuda, memanah atau berenang. Banyak hadist Nabi yang menganjurkan umatnya agar memiliki kekuatan fisik. Dari gambaran tersebut, dapat dikatakan bahwa pendidikan Islam sangat memperhatikan masalah perkembangan fisik dan pelatihan angota tubuh yang diarahkan untuk kebaikan manusia dan masyarakat. Pengarahan tersebut dilakukan melalui dua langkah berikut, pertama, mengarahkan kekuatan pada segala perkara yang diridlai Allah, misalnya untuk membantu orang yang sedang mengalami kesulitan. Kedua, menjauhkan kekuatan fisik dari segala perkara yang dibenci Allah, seperti memberatkan hukuman, menyulut permusuhan dll.

\section{d. Pendidikan Islam dan Konsep Perkembangan Akal}

Dalam pandangan Islam, akal merupakan potensi manusiawi yang paling penting. Itulah yang mendasari pemahaman dan kesempurnaan akal dalam rukun iman. Lebih jauh lagi, al-Qur`an menganjurkan penggunaan akal dalam merenungi tanda-tanda kebesaran Allah yang ada pada diri manusia atau yang ada pada alam semesta. Dalam rangka merealisasikan keimanan dan ketaatan kepadaNya,pendidikan Islam mengajak manusia untuk memanfaatkan akal dalam berargumentasi, mencari kepuasan, merenung dan melakukan observasi. Jelasnya 
186 - 199 | Tafhim Al-`Ilmi, Februari 2020

pendidikan Islam mengembangkan akal menurut pola perkembangan yang terbaik, sehingga tidak akan ada manusia berakal yang sombong karena pendidikan Islam menghindarkan manusia dari eksploitasi nafsu dan syahwat.Dengan demikian konsep pendidikan Islambertujuan untuk mengembangkan akal manusia yang disempurnakan dengan pengembangan jasmaniah. Dalam pendidikan Islam, aspek intelektual berkembang dari kecermatan dan kejujuran berpikir serta aplikasi praktis menuju pengakuan adanya Dzat Yang Maha Tinggi, melalui pencarian petunjuk serta penjauhan diri dari eksploitasi hawa nafsu.

\section{e. Pendidikan Islam dan Konsep Perkembangan Sosial}

Dalam kerangka pendidikan secara umum perkembangan sosial meliputi aspek perkembangan perasaan kemasyarakatan, perkembangan pengalaman kemasyarakatan dan perkembangan imajinasi kemasyarakatan. Dalam pendidikan Islam, tujuan perasaan kemasyarkatan didefinisikan sebagai upaya mempersatukan individu yang bercerai berai, realisasi tujuan tersebut memerlukan konsistensi individu dalam berpikir, beribadah dan mempraktikan syariat pada konsepsi Islam tentang alam semesta. Dengan konsep pendidikan Islam,berarti kita telah mempersiapkan anak-anak dalam pengembangan ikatan sosialnya sehingga dalam praktiknya anak-anak akan terhindar dari praktik diskriminasi, kedzoliman dan kejahatan-kejahatan lainnya. Dengan demikian keterkaitan pendidikan islam terwujud hnya karena agama yang satu, bukan karena kesamaan bahasa atau nasionalisme semata.

\section{d. Metode Pendidikan Islam}

Pada dasarnya, metode pendidikan islam sangat efektif dalam membina kepribadian anak didik dan memotivasi mereka sehingga aplikasi metode ini memungkinkan puluhan ribu kaum mukminin dapat membuka hati manusia untuk menerima petunjuk Ilahi dan konsep-konsep peradaban islam. Selain itu, metode pendidikan Islam akan mampu menempatkan manusia di permukaan bumi dan dalam lamanya masa yang tidak diberikan pada penghuni bumi lainnya. 
Metode yang dianggap paling penting dan paling menonjol adalah :

1. Metode dialog Qur`ani dan Nabawi

2. Mendidik melalui kisah-kisah qur`ani dan nabawi

3. Mendidik melalui perumpamaan Qur`ani dan Nabawi

4. Mendidik melalui keteladanan

5. Mendidik melalui aplikasi dan pengamalan

6. Mendidik melalui ibrah dan nasihat

7. Mendidik melalui targhib dan $\operatorname{tarhib}^{7}$

Pendidikan Islam tampil melalui tujuan yang sarat dengan konsepsi ketuhanan. Suatu konsep yang berhubungan dengan ketuhanan memiliki berbagai keutamaan yaitu :

1. Bersumber pada kesempurnaan ilahi sehingga sifat pendidikannya pun sempurna.

2. Meliputi segala aspek kehidupan manusia sehingga bersifat universal

3. Mencakup seluruh aspek kemanusiaan, tidak dikhususkan pada bangsa tertentu

4. Bersumber dari keberadaanya di sisi Allah sehingga dapat eksis dan lestari sepanjang masa

5. Sangat selaras dengan fitrah kemanusiaan, artinya dalam aplikasi tidak menghilangkan segala potensi manusia

6. Sangat kaya dengan hasil yang memuaskan karena tidak bertentangan dengan fitrah manusia serta tidak merintangi penyaluran potensi manusia

7. Sesuai dengan fitrah psikologis dan intelektual manusia sehingga menjadi tujuan yang jelas dan mudah dipahami seluruh manusia

8. Mengantarkan manusia pada keseimbangan, keselarasan, keseimbangan antaraspek, serta keharmonisan hubungan antar aspek. Buah yang dihasilkan dari hal yang seperti itu adalah terhimpunnya seluruh aspek dalam tujuan yang sama.

\footnotetext{
${ }^{7}$ Departemen Agama Republik Indonesia, Al-Qur'an dan Terjemahannya, Bandung, Gema Risalah Press, 1992
} 
188 - 199 | Tafhim Al-`Ilmi, Februari 2020

9. Sangat realistis, mudah diaplikasikan, dan berpengaruh pada perilaku seluruh manusia walaupun berasal dari budaya dan usia yang berbeda.

10. Sangat elastis sehingga selalu relevan dengan berbagai situasi dan kondisi manusia walaupun manusia itu berada dalam berbagai waktu, wilayah, atau pola hidup yang bervariasi ${ }^{8}$.

Islam menawarkan konseptualisasi pendidikan, yang berintikan ilmu naqliyah yang melandasi semua ilmu aqliyah, sehingga diharapkan dapat mengintegrasikan antara akal dan wahyu, ilmu-ilmu syar'iyyah dan ilmu-ilmu ghairu syar'iyyah dalam proses pendidikan. Sehingga, melalui upaya tersebut dapat merealisasikan proses memanusiakan manusia sebagai tujuan pendidikan, yaitu mengajarkan, mengasuh, melatih, mengarahkan, membina dan mengembangkan seluruh potensi peserta didik dalam rangka menyiapkan mereka merealisasikan fungsi dan risalah kemanusiaannya di hadapan Allah SWT, yaitu mengabdi sepenuhnya kepada Allah SWT dan menjalankan misi kekhalifahan di muka bumi, sebagai makhluk yang berupaya mengiplementasikan nilai-nilai ilahiyah dengan memakmurkan kehidupan dalam tatanan hidup bersama dengan aman, damai dan sejahtera ${ }^{9}$.

\section{Poblematika Pendidikan Islam}

\section{a. Pengertian Problematika Pendidikan Islam}

Dapat penulis simpulkan dari pengertian problematika + pendidikan islam. Berarti problematika pendidikan islam adalah masalah-masalah yang terjadi dalam pendidikan islam.

\section{b. Poblematika Pendidikan Islam Modern}

Ketertinggalan pendidikan Islam salah satunya dikarenakan oleh terjadinya penyempitan terhadap pemahaman pendidikan Islam yang hanya berkisar pada aspek kehidupan ukhrawi yang terpisah dengan kehidupan duniawi, atauaspek kehidupan rohani yang terpisah dengan kehidupan jasmani ${ }^{10}$.

\footnotetext{
${ }^{8}$ Jalaluddin, Teologi Pendidikan, Jakarta: PT. RajaGrafindo Persada, 2003

${ }^{9}$ MuhammadNatsir, Kapita Selekta, Bandung, Gravenhage, 1954

${ }^{10}$ Samsul Nizar, Pengantar Dasar-Dasar Pemikiran Pendidikan Islam, Jakarta: Gaya Media Pratama, 2001
} 
Oleh karena itu, akan tampak adanya perbedaan dan pemisahan antara yang dianggap agama dan bukan agama, yang sakral dengan yang profan, antara dunia dan akhirat. Cara pandang yang memisahkan antara yang satu dengan yang lain ini disebut sebagai cara pandang dikotomi. Adanya dikotomi inilah yang salah satu penyebab ketertinggalan pendidikan Islam. Hingga kini pendidikan Islam masih memisahkan antaraakal dan wahyu, serta pikir dan zikir. Hal ini menyebabkan adanya ketidakseimbangan pola fikir, yaitu kurang berkembangnya konsep humanisme religius dalam dunia pendidikan Islam, karena pendidikan Islam lebih berorientasi pada konsep 'abdullah (manusia sebagai hamba), ketimbang sebagai konsep khalifatullah (manusia sebagai khalifah Allah).

\section{a. Masalah Mendasar}

\section{Sekularisme sebagai Paradigma Pendidikan}

Sekularisme adalah suatu paham yang memisahkan antara dunia dan akhirat, kehidupan dunia dan agama, pengalaman agama adalah masalah pribadi.

Jarang ada orang mau mengakui dengan jujur, sistem pendidikan kita adalah sistem yang sekular-materialistik. Biasanya yang dijadikan argumentasi, adalah UU Sisdiknas No. 20 tahun 2003 Bab II Pasal 3 yang berbunyi, "Pendidikan nasional bertujuan berkembangnya potensi peserta didik agar menjadi manusia yang beriman dan bertakwa kepada Tuhan Yang Maha Esa, berakhlak mulia, sehat, berilmu, cakap, kreatif, mandiri dan menjadi warga negara yang demokratis serta bertanggungjawab."

Tapi perlu diingat, sekularisme itu tidak otomatis selalu anti agama. Tidak selalu anti "iman" dan anti "taqwa". Sekularisme itu hanya menolak peran agama untuk mengatur kehidupan publik, termasuk aspek pendidikan. Jadi, selama agama hanya menjadi masalah pribadi dan tidak dijadikan asas untuk menata kehidupan publik seperti sebuah sistem pendidikan, maka sistem pendidikan itu tetap sistem pendidikan sekular, walaupun para individu pelaksana sistem itu beriman dan bertaqwa (sebagai perilaku individu). 
190 - 199 | Tafhim Al-`Ilmi, Februari 2020

Sesungguhnya diakui atau tidak, sistem pendidikan kita adalah sistem pendidikan yang sekular-materialistik. Hal ini dapat dibuktikan antara lain pada UU Sisdiknas No. 20 tahun 2003 Bab VI tentang jalur, jenjang dan jenis pendidikan bagian kesatu (umum) pasal 15 yang berbunyi: "Jenis pendidikan mencakup pendidikan umum, kejuruan, akademik, profesi, advokasi, keagamaan, dan khusus".

Dari pasal ini tampak jelas adanya dikotomi pendidikan, yaitu pendidikan agama dan pendidikan umum. Sistem pendidikan dikotomi semacam ini terbukti telah gagal melahirkan manusia yang berkepribadian Islam sekaligus mampu menjawab tantangan perkembangan melalui penguasaan sains dan teknologi.

Secara kelembagaan, sekularisasi pendidikan tampak pada pendidikan agama melalui madrasah, institut agama, dan pesantren yang dikelola oleh Departemen Agama; sementara pendidikan umum melalui sekolah dasar, sekolah menengah, kejuruan serta perguruan tinggi umum dikelola oleh Departemen Pendidikan Nasional. Terdapat kesan yang sangat kuat bahwa pengembangan ilmu-ilmu kehidupan (iptek) dilakukan oleh Depdiknas dan dipandang sebagai tidak berhubungan dengan agama.

Pembentukan karakter siswa yang merupakan bagian terpenting dari proses pendidikan justru kurang tergarap secara serius. Agama ditempatkan sekadar sebagai salah satu aspek yang perannya sangat minimal, bukan menjadi landasan dari seluruh aspek kehidupan ${ }^{11}$.

\section{Permasalahan lain}

Masalah-masalah cabang yang dimaksud di sini, adalah segala masalah selain masalah paradigma pendidikan, yang berkaitan dengan penyelenggaraan pendidikan. Masalah-masalah cabang ini tentu banyak sekali macamnya, di antaranya yang terpenting adalah sebagai berikut.

\footnotetext{
${ }^{11}$ Redaksi Penerbit, Standar Nasional Pendidikan, Jakarta: Asa Mandiri, 2006
} 
1. Perkembangan Ilmu Pengetahuan dan teknologi Yang Tidak Memperhatikan Masalah Agama

Pendidikan Islam saat ini menghadapi masalah serius yang berkaitan dengan perubahan masyarakat yang terus menerus semakin cepat, lebih-lebih perkembangan ilmu pengetahuan yang hampir tidak memperdulikan sistem suatu agama.Kondisi sekarang ini, pendidikan Islam berada pada posisi determinisme historik dan realisme. Dalam artian bahwa, satu sisi umat Islam berada padaromantisme historis di mana mereka bangga karena pernah memiliki para pemikir-pemikir dan ilmuwan-ilmuwan besar danmempunyai kontribusi yang besar pula bagi pembangunan peradaban dan ilmu pengetahuan dunia sertamenjadi transmisi bagi khazanah Yunani, namun di sisi lain mereka menghadapi sebuahkenyataan, bahwa pendidikan Islam tidak berdaya dihadapkan kepada realitas masyarakatindustri dan teknologi modern. Hal ini pun didukungdengan pandangan sebagian umat Islam yang kurangmeminati ilmu-ilmu umum dan bahkan sampai pada tingkat "diharamkan".

2. Terjadi Pemilahan Antara Ilmu Umum dan Ilmu Agama

Terjadinya pemilahan-pemilahan antara ilmu umum dan ilmu agama inilah yang membawa umat Islam kepada keterbelakangan dan kemunduran peradaban, lantaran karena ilmu-ilmu umum dianggap sesuatu yang berada di luar Islam dan berasal dari non-Islam. Agama dianggap tidak ada kaitannya dengan ilmu, begitu juga ilmu dianggap tidak memperdulikan agama, padahal sesungguhnya semua ilmu berasal dari al-Quran. Begitulah gambaran praktik kependidikan dan aktivitas keilmuan di tanah air sekarang ini dengan berbagai dampak negatif yang ditimbulkan dan dirasakan oleh masyarakat. Sistem pendidikan Islam yang ada hanya mengajarkan ilmu-ilmu agama saja. Di sisi lain, generasi muslim yang menempuh pendidikan di luar sistem pendidikan Islam hanya mendapatkan porsi kecil dalam hal pendidikan Islam atau bahkan sama sekali tidak mendapatkan ilmu-ilmu keislaman ${ }^{12}$.

\footnotetext{
${ }^{12}$ UmarShihab,Kontekstualitas Al-Qur'an; Kajian Tematik Atas Ayat-Ayat Hukum Dalam AlQur'an, Jakarta: Penamadani, 2005
} 
192 - 199 | Tafhim Al-`Ilmi, Februari 2020

\section{Rendahnya Kualitas Sarana Fisik}

Untuk sarana fisik misalnya, banyak sekali sekolah dan perguruan tinggi kita yang gedungnya rusak, kepemilikan dan penggunaan media belajar rendah, buku perpustakaan tidak lengkap. Sementara laboratorium tidak standar, pemakaian teknologi informasi tidak memadai dan sebagainya. Bahkan masih banyak sekolah yang tidak memiliki gedung sendiri, tidak memiliki perpustakaan, tidak memiliki laboratorium dan sebagainya.

4. Rendahnya Kualitas Guru

Keadaan guru di Indonesia juga amat memprihatinkan. Kebanyakan guru belum memiliki profesionalisme yang memadai untuk menjalankan tugasnya sebagaimana disebut dalam pasal 39 UU No 20/2003 tentang Sisdiknas yaitu merencanakan dan melaksanakan proses pembelajaran, menilai hasil pembelajaran, melakukan pembimbingan dan pelatihan serta melakukan penelitian dan pengabdian kepada masyarakat.

Dari pasal tersebut, maka syarat-syarat untuk menjadi guru dapat disimpulkan sebagai berikut:

a. Berijazah

b. Sehat jasmani dan rohani

c. Takwa kepada Tuhan YME dan berkelakuan baik

d. Bertanggung jawab

e. Berjiwa nasional

Walaupun guru bukan satu-satunya faktor penentu keberhasilan pendidikan tetapi guru merupakan titik sentral pendidikan dan kualifikasi, sebagai cermin kualitas, tenaga pengajar memberikan andil sangat besar pada kualitas pendidikan yang menjadi tanggung jawabnya.

\section{Rendahnya Kesejahteraan Guru}

Rendahnya kesejahteraan guru mempunyai peran dalam membuat rendahnya kualitas pendidikan Indonesia. Berdasarkan survei FGII (Federasi Guru Independen Indonesia) pada pertengahan tahun 2005, idealnya seorang guru menerima gaji bulanan sebesar Rp 3 juta rupiah. Sekarang, pendapatan rata-rata guru PNS per bulan sebesar Rp 1,5 juta. guru bantu Rp. 460 ribu, dan guru 
honorer di sekolah swasta rata-rata $\mathrm{Rp} 10$ ribu per jam. Dengan pendapatan seperti itu, terang saja, banyak guru terpaksa melakukan pekerjaan sampingan. Ada yang mengajar lagi di sekolah lain, memberi les pada sore hari, menjadi tukang ojek, pedagang mie rebus, pedagang buku/LKS, pedagang pulsa ponsel, dan sebagainya. Dan itu semua mengganggu terhadap efektifitas pembelajaran.

Dengan adanya UU Guru dan Dosen, barangkali kesejahteraan guru dan dosen (PNS) agak lumayan. Pasal 10 UU itu sudah memberikan jaminan kelayakan hidup. Di dalam pasal itu disebutkan guru dan dosen akan mendapat penghasilan yang pantas dan memadai, antara lain meliputi gaji pokok, tunjangan yang melekat pada gaji, tunjangan profesi, dan/atau tunjangan khusus serta penghasilan lain yang berkaitan dengan tugasnya. Mereka yang diangkat pemkot/pemkab bagi daerah khusus juga berhak atas rumah dinas.

Tapi, kesenjangan kesejahteraan guru swasta dan negeri menjadi masalah lain yang muncul. Di lingkungan pendidikan swasta, masalah kesejahteraan masih sulit mencapai taraf ideal. Diberitakan Pikiran Rakyat 9 Januari 2006, sebanyak 70 persen dari 403 PTS di Jawa Barat dan Banten tidak sanggup untuk menyesuaikan kesejahteraan dosen sesuai dengan amanat UU Guru dan Dosen.

\section{c. Faktor-Faktor yang Mempengaruhi Timbulnya Masalah Pendidikan}

\section{Islam}

Masalah pendidikan Islam timbul karena dua faktor yaitu faktor internal dan eksternal.

\section{Faktor internal}

Meliputi manajemen pendidikan Islam yang pada umumnya belum mampu menyelenggarakan pembelajaran dan pengelolaan pendidikan yang efektif dan berkualitas. Hal ini tercermin dari kalah bersaing dengan sekolah-sekolah yang berada di bawah pembinaan Departemen Pendidikan Nasional [Diknas] yang umumnya dikelola secara modern.

Faktor kompensasi profesional guru yang masih sangat rendah. Para guru

yang merupakan unsur terpenting dalam kegiatan belajarmengajar, umumnya lemah dalam penguasaan materi bidang studi, terutama menyangkut bidang studi 
umum, ketrampilan mengajar, manajemen keles, dan motivasi mengajar. Hal ini terjadi karena sistem pendidikan Islam kurang kondusif bagi pengembangan kompetensi profesional guru.

Adalah faktor kepemimpinan, artinya tidak sedikit kepala-kepala madrasah yang tidak memiliki visi, dan misi untuk mau ke mana pendidikan akan dibawa dan dikembangkan. Kepala madrasah seharusnya merupakan simbol keunggulan dalam kepemimpinan, moral, intelektual dan profesional dalam lingkungan lembaga pendidikan formal, ternyata sulit ditemukan di lapangan pendidikan Islam. Pimpinan pendidikan Islam bukan hanya sering kurang memiliki kemampuan dalam membangun komunikasi internal dengan para guru, melainkan juga lemah dalam komunikasi dengan masyarakat, orang tua, dan pengguna pendidikan untuk kepentingan penyelenggaraan pendidikan yang berkualitas. Biasanya pendekatan yang digunakan adalah pendekatan birokratis daripada pendekatan kolegial profesional. Mengelola pendidikan bukan berdasar pertimbangan profesional, melainkan pendekatan like anddislike (Mahfudh Djunaidi, 2005), dengan tidak memiliki visi dan misi yang jelas.

\section{Faktor eksternal}

Adanya perlakuan diskriminatif pemerintah terhadap pendidikan Islam. Pemerintah selama ini cenderung menganggap dan memperlakukan pendidikan Islam sebagai anak tiri, khususnya soal dana dan persoalan lain. Katakan saja, alokasi dana yang diberikan pemerintah sangat jauh perbedaannya dengan pendidikan yang berada di lingkungan Diknas. Maka, terlepas itu semua, apakah itu urusan Depag atau Depdiknas, mestinya alokasi anggaran negara pada pendidikan Islam tidak terjadi kesenjangan, toh pendidikan Islam juga bermisi untuk mencerdaskan bangsa, sebagaimana juga misi yang diemban oleh pendidikan umum. ${ }^{13}$

Dapat dikatakan bahwa paradigma birokrasi tentang pendidikan Islam selama ini lebih didominasi oleh pendekatan sektoral dan bukan pendekatan

\footnotetext{
${ }^{13}$ Tim Penyusun Kamus Pusat Pembinaan dan Pengembangan Bahasa, Kamus Besar Bahasa Indonesia, Jakarta: Balai Pustaka, 1989
} 
fungsional. Pendidikan Islam tidak dianggap bagian dari sektor pendidikan, lantaran urusannya tidak di bawah Depdiknas. Beberapa indikator yang menunjukkan kesenjangan ini yaitu mulai dari tingkat ketersediaan tenaga guru, status guru, kondisi ruang belajar, tingkat pembiayaan (unit cost) siswa, hingga tidak adanya standardisasi mutu pendidikan Islam, karena urusan pendidikan Islam tidak berada di bawah Depdiknas dan lebih tragis lagi adalah sikap diskriminatif terhadap prodak atau lulusan pendidikan Islam.

Adalah adanya diskriminasi masyarakat terhadap pendidikan Islam. Secara jujur harus diakui, bahwa masyarakat selama ini cenderung acuh terhadap proses pendidikan di madrasah atau sekolah-sekolah Islam. Rata-rata memandang pendidikan Islam adalah pendidikan nomor dua dan biasanya bila menyekolahkan anaknya di lembaga pendidikan Islam merupakan alternatif terakhir setelah tidak dapat diterima di lembaga pendidikan di lingkungan Diknas ${ }^{14}$.

\section{d. Solusi Problematika Pendidikan Islam}

Solusi Problematika Pendidikan Islam saat ini mencermati kenyatan tersebut, maka mau tidak mau persoalan konsep dualisme-dikotomik pendidikan harus segera ditumbangkan dan dituntaskan, baik pada tingkatan filosofis-paradigmatik maupun teknis departementel. Pemikiran filosofis menjadi sangat penting, karena pemikiran ini nanti akan memeberikan suatu pandangan dunia yang menjadi landasan idiologis dan moral bagi pendidikan ${ }^{15}$.

a.1) Solusi Problem Mendasar: Sekularisme sebagai Paradigma Pendidikan

Penyelesaian problem mendasar tentu harus dilakukan secara fundamental. Itu hanya dapat diwujudkan dengan melakukan perombakan secara menyeluruh yang diawali dari perubahan paradigma pendidikan sekular menjadi paradigma Islam. Ini sangat penting dan utama.

Ibarat mobil yang salah jalan, maka yang harus dilakukan adalah mengubah haluan atau arah mobil itu terlebih dulu, menuju jalan yang benar agar bisa sampai ke tempat tujuan yang diharapkan. Tak ada artinya mobil itu diperbaiki

14 Abdurrahman An-Nahlawi. Pendidikan Islam di rumah, sekolah dan masyarakat, Bandung: Gema Insani Press . 1986

${ }^{15}$ Prof. Dr. Made Pidarta. Landasan Kependidikan. Jakarta: Rineka Cipta. 1981 
196 - 199 | Tafhim Al-`Ilmi, Februari 2020

kerusakannya yang macam-macam selama mobil itu tetap berada di jalan yang salah. Setelah membetulkan arah mobil ke jalan yang benar, barulah mobil itu diperbaiki kerusakannya yang bermacam-macam.

Artinya, setelah masalah mendasar diselesaikan, barulah berbagai macam masalah cabang pendidikan diselesaikan, baik itu masalah rendahnya sarana fisik, kualitas guru dan kesejahteraan guru.

Solusi masalah mendasar itu adalah merombak total asas sistem pendidikan yang ada, dari asas sekularisme diubah menjadi asas Islam, bukan asas yang lain.

Bentuk nyata dari solusi mendasar itu adalah mengubah total UU Sistem Pendidikan yang ada dengan cara menggantinya dengan UU Sistem Pendidikan Islam. Hal paling mendasar yang wajib diubah tentunya adalah asas sistem pendidikan. Sebab asas sistem pendidikan itulah yang menentukan hal-hal paling prinsipil dalam sistem pendidikan, seperti tujuan pendidikan dan struktur kurikulum $^{16}$.

b.1) Solusi terhadap perkembangan Ilmu Pengetahuan dan Teknologi yang tidak memperhatikan masalah agama

Untuk menyelesaikan masalah ini, penulis kira pendidikan islam harus segera menguasai pendidikan berbasis teknologi, agar pendidikan islam tidak jauh tertinggal dalam pendidikan.

b.2 )Solusi tentang pemisahan antar ilmu dan agama

Pemisahan antar ilmu dan agama hendaknya segera dihentikan dan menjadi sebuah upaya penyatuan keduannya dalam satu sistem pendidikan integralistik. Namun persoalan integrasi ilmu dan agama dalam satu sistem pendidikan ini bukanlah suatu persoalan yang mudah, melainkan harus atas dasar pemikiran filosofis yang kuat, sehingga tidak terkesan hanya sekedar tambal sulam. Langkah awal yang harus dilakukan dalam mengadakan perubahan pendidikan adalah merumuskan "kerangka dasar filosofis pendidikan" yang sesuai dengan ajaran Islam, kemudian mengembangkan secara "empiris prinsip-prinsip" yang mendasari terlaksananya dalam konteks lingkungan (sosio dan kultural) Filsafat Integralisme (hikmah wahdatiyah) adalah bagian dari filsafat Islam yang menjadi

\footnotetext{
${ }^{16}$ Ahmad Tafsir. Metodologi Pengajaran Agama Islam. Bandung: Remaja Rosdakarya. 2001.
} 
alternatif dari pandangan holistik yang berkembang pada era postmodern di kalangan masyarakat barat.

Inti dari pandangan hikmah wahdatiyah ini adalah bahwa yang mutlak dan yang nisbi merupakan satu kesatuan yang berjenjang, bukan sesuatu yang terputus sebagaimana pandangan ortodoksi Islam. Pandangan Armahedi Mahzar, pencetus filsafat integralisme ini, tentang ilmu juga atas dasar asumsi di atas, sehingga dia tidak membedakan antara ilmu agama dan ilmu umum, ilmu Tuhan dan ilmu skular, ilmu dunia dan ilmu akhirat. Dari pandangan dia tentang kesatuan tersebut juga akan berimplikasi pula pada pemikiran Armahedi pada permasalahan yang lain, termasuk juga pendidikan Islam ${ }^{17}$.

Bagi Armahedi, pendidikan Islam haruslah menjadi satu kesatuan yang utuh atau integral. Baginya, manusia-manuisa saat ini merupakan produk dari pemikiran Barat Modern yang mengalami suatu kepincangan, karena merupakan suatu perkembangan yang parsial. Peradaban Islam adalah contoh lain. Keduanya dapat ditolong dengan membelokkan arah perkembangannya ke arah perkembangan yang evolusioner yang lebih menyeluruh dan seimbang. Hanya ada beberpa sisi saja dari kehidupan manusia yang dikembangkan. Begitu juga halnya dengan masyarakat yang ada, pada hakikatnya adalah cerminan dari satu sistem pendidikan yang ada saat itu.

Masyarakat saat ini adalah masyarakat materialis yang dapat dibina dengan menggunakan suatu mesin raksasa yang bernama teknostrutur. Di sini ada satu link yang hilang, yaitu spiritualisme. Dengan demikian, pendidikan sebagai produksi sistem ini haruslah mengembangkan seluruh aspek dari manusia dan masyarakat sesuai dengan fitrah Islam, yaitu tauhid.

Pandangan filosofis inilah yang menjadikan pentingnya kajian terhadap pemikiran Armahedi Mahzar tentang sistem pendidikan Islam integratif, karena permasalahan pendidikan sebenarnya terletak pada dua aspek, filosofis dan praktis. Persoalan filosofis ini yang menjadi landasan pada ranah praktis pendidikan. Ketika ranah filosofis telah terbangun kokoh, maka ranah praktis akan

\footnotetext{
${ }^{17}$ M.I.Soelaeman. Pendidikan dalam Keluarga. Bandung: Alfabeta. 1994
} 
198 - 199 | Tafhim Al-`Ilmi, Februari 2020

berjalan secara sistematis. Dengan demikian, filsafat integralisme atau hikmah wahdatiyah nantinya akan menjadi landasan idiologis dalam pengembangan sistem pendidikan integratif.

b.3.4.5 ) Rendahnya sarana fisik, Rendahnya kualitas guru dan kesejahteraan guru

Untuk mengatasi masalah-masalah cabang di atas, secara garis besar ada dua solusi yaitu:

Pertama, solusi sistemik, yakni solusi dengan mengubah sistem-sistem sosial yang berkaitan dengan sistem pendidikan Islam. Seperti diketahui sistem pendidikan sangat berkaitan dengan sistem ekonomi yang diterapkan. Sistem pendidikan di Indonesia sekarang ini, diterapkan dalam konteks sistem ekonomi kapitalisme yang berprinsip antara lain meminimalkan peran dan tanggung jawab negara dalam urusan publik, termasuk pendanaan pendidikan.

Maka, solusi untuk masalah-masalah cabang yang ada, khususnya yang menyangkut perihal pembiayaan seperti rendahnya sarana fisik dan kesejahteraan guru berarti menuntut juga perubahan sistem ekonomi yang ada. Akan sangat kurang efektif kita menerapkan sistem pendidikan Islam dalam atmosfer sistem ekonomi kapitalis yang kejam. Maka sistem kapitalisme saat ini wajib dihentikan dan diganti dengan sistem ekonomi Islam yang menggariskan bahwa pemerintahlah yang akan menanggung segala pembiayaan pendidikan negara.

Kedua, solusi teknis, yakni solusi yang menyangkut hal-hal teknis yang berkaitan langsung dengan pendidikan. Solusi ini misalnya untuk menyelesaikan masalah kualitas guru.

Maka, solusi untuk masalah-masalah teknis dikembalikan kepada upayaupaya praktis untuk meningkatkan kualitas sistem pendidikan. Rendahnya kualitas guru, misalnya, di samping diberi solusi peningkatan kesejahteraan, juga diberi solusi dengan membiayai guru melanjutkan ke jenjang pendidikan yang lebih tinggi dan memberikan berbagai pelatihan untuk meningkatkan kualitas guru.

Kedua, solusi teknis, yakni solusi yang menyangkut hal-hal teknis yang berkaitan langsung dengan pendidikan. Solusi ini misalnya untuk menyelesaikan masalah kualitas guru. 


\section{DAFTAR PUSTAKA}

Anshari, Endang Saefuddin, Pokok-Pokok Pikiran tentang Islam, Usaha Enterprise, Jakarta: Media Citra, 1976.

Azra, Azyumardi, Pendidikan Islam, Tradisi dan Modernisasi Menuju Milenium Baru, Jakarta: Logos, Wacana Ilmu. 1997.

Arifin, Muzayyin, Filsafat Pendidikan Islam, Jakarta: Bumi Aksara, 2003.

Cowie, Hornby, Oxford Advanced Learners Dictionary of Current English, London:Oxford University Press, 1974.

Departemen Agama Republik Indonesia, Al-Qur'an dan Terjemahannya, Bandung, Gema Risalah Press, 1992

Jalaluddin, Teologi Pendidikan, Jakarta: PT. RajaGrafindo Persada, 2003.

Natsir, Muhammad, Kapita Selekta, Bandung, Gravenhage, 1954.

Nizar, Samsul, Pengantar Dasar-Dasar Pemikiran Pendidikan Islam, Jakarta: Gaya Media Pratama, 2001.

Redaksi Penerbit, Standar Nasional Pendidikan, Jakarta: Asa Mandiri, 2006.

Shihab, Umar, Kontekstualitas Al-Qur'an; Kajian Tematik Atas Ayat-Ayat Hukum Dalam Al-Qur'an, Jakarta: Penamadani, 2005.

Shihab, Quraish, Tafsir Al-Misbah, Pesan, Kesan dan Keserasian Al-Qur'an, Jakarta: Lentera Hati, 2002.

Tim Penyusun Kamus Pusat Pembinaan dan Pengembangan Bahasa, Kamus Besar Bahasa Indonesia, Jakarta: Balai Pustaka, 1989.

Abdurrahman An-Nahlawi . Pendidikan Islam di rumah, sekolah dan masyarakat, Bandung: Gema Insani Press . 1986.

Prof. Dr. Made Pidarta. Landasan Kependidikan. Jakarta: Rineka Cipta. 1981.

DR. Ahmad Tafsir. Metodologi Pengajaran Agama Islam. Bandung: Remaja Rosdakarya. 2001.

DR.M.I.Soelaeman. Pendidikan dalam Keluarga. Bandung: Alfabeta. 1994. 